\title{
PERFORMANCE IS INFLUENCED BY JOB INSECURITY AND OCCUPATIONAL SAFETY HEALTH
}

\author{
Dirga Lestari $^{1 *}$ and Siti Maria ${ }^{2}$ \\ ${ }^{1,2}$ Mulawarman University, Samarinda
}

\begin{abstract}
The purpose of this study was to investigate the influence between Job Insecurity and Occupational Safety and Health (OSH). It was expected that Job Insecurity was positively related to Job Performance and to Occupational Safety and Health (OSH). Some Firefighter And Rescue Department in East Kutai Regency sampled in this study and the result of the proposed hypothesis is acceptable. Job insecurity was in fact positively correlated with Job Performance and positively with Occupational Safety and Health (OSH). However, results of this research indicate to improve the performance required not only the safety and personal health of employees physically but also the work security from the psychological side of within the workers themselves. This applies not only to firefighters but also to other sector workers. Limitations of the study are the use of a sample of only one hundred and twenty-six firefighter and a need for more in-depth interviews to more Firefighter And Rescue Department in East Kutai Regency.
\end{abstract}

Keywords: Job Insecurity, Occupational Safety and Health, Performance

\section{INTRODUCTION}

Good Human Resource Management will provide significant progress for the organization. One of the factors that need to be considered to achieve the desired target is to pay attention to job insecurity and the existence of occupational safety and health programs for employees to improve their performance. With the program, every employee will get health and safety guarantee both physically, socially, and psychologically so that every employee feel safe and protected in work. Anxiety problems perceived by employees, safety and work-related illness can not be viewed as a minor problem because it can cause many harm to both employees and organizations. Concrete losses can include medical expenses, a desire to quit, a decrease in production that will result in a decline in performance that can even result in lifelong disability or death for employees.

The intensity of the emergence of job insecurity is increasingly felt by employees when they feel that at any time there is a possibility that they will move positions, move their work to other areas, or even out of the agency where they work. Because in doing his job, every employee as a humans certainly crave comfort and safety in work. Security in this context does not mean only safe from workplace accidents, but far from it, a sense of security from the threat of job loss. This sense of security can be a tremendous stimulator in maintaining a long-term employee attitude. Job insecurity has a psychological impact on employees in the form of decreasing job satisfaction that will be fatal to the overall performance of the organization.

Occupational Safety and Health (OSH) which neglected also resulted in a decrease in performance and may result in all forms of activities or operations

* Corresponding author. Email address: dirga.lestari.as@ feb.unmul.ac.id 
of the company will be disrupted. With increasing cases of work accidents and the resulting losses and increased potential hazards in the production process, effective and efficient management of Occupational Health and Safety (OSH) in all organizational elements is required. To anticipate these threats then Government R.I. has succeeded in formulating and enacting Laws which provide legal protection as stated in Law number 1 of 1970 and number 23 of 1992 which guarantees and regulates Occupational Safety and Health (OSH). But the implementation of that Laws still has not been applied maximally so that the risk of work accident hazard due to human error is still happens often.

Along with the high population, density and land use can be a potential for fire. Various problems caused by population density such as dense settlements, buildings, and public facilities may pose a risk of fire. The fire hazard is one of the most unpredictable and unpredictable disasters when it comes, but the fire hazards can be reduced by giving full awareness of the goods that could result in a faulty source of fire and electronic goods. Strategy is very useful compared to the act of extinguishing when the fire is out of control. Fire is one of the disasters that can be classified as both natural and non-natural disasters based on the cause of the fire, causing loss of life, environmental damage, and property loss. Therefore the role of government and citizens is very important to prevent and cope with fires.

One of the institutions to tackle the fire that formed by local government in East Kutai is Fire and Rescue Department. This department has the main duty to implement some regional authorities in the field of fire prevention and handling which includes prevention, guidance, counseling, and operational control. When viewed from the substance of the role of the importance of the Fire and Rescue Department in terms of tackling fires, it is necessary to provide excellent service quality to provide fire management services that are increasingly prevalent in the end of this decade. Whereas based on the law no 24 article 6 of 2007 the government and local governments become responsible for the implementation of disaster management.

Meanwhile, in East Kutai Regency still reap many cases related to public criticism of the services provided by that department. This is reinforced by public complaints about fire service proving that the Fire and Rescue Department in East Kutai still not stable in maintaining the achievement of its performance, so needed a system that regulate and oversee the course of human resource activity owned bye Fire and Rescue Department in East Kutai. In other words the role and function of management is needed for the creation of the organization's goals. From the observation in the field there is an indication of the decline in employee performance that will have implications on the process of achieving the objectives of the department, so it needs to be studied how Job Insecurity and Occupational Safety and Health (OSH) variables affect employee performance.

\section{LITERATURE STUDY/HYPOTHESES DEVELOPMENT}

Scientific interest in job insecurity has started since thirty years ago with the publication of famous articles, "Job Insecurity: Toward Conceptual Clarity", by Greenhalgh and Rosenblatt (1984). Job insecurity is a condition of powerlessness to maintain the desired sustainability in a threatening work situation. Job insecurity leads to psychological impact in employees. Among the psychological aspects that arise include the decrease in job satisfaction, 
decreased creativity, feelings of gloom and guilt, anxiety and even anger (Band dan Tustin, 1999).

Job insecurity can be likened to feeling threatened to unemployment (Mohr,2000). Job insecurity also contains references about undesirable properties in a job (Sverke \& Hellgren, 2002). Job insecurity implies a discrepancy between what is 'desired' by the employee (security about the future of their current job) and what they 'get' (the perception that the job is now insecure). Rosenblatt, Talmud, and Ruvio (1999) found that job insecurity was associated with performance degradation. So as Cheng dan Chan (2008) found a significant relationship between job insecurity and performance. However, other studies have shown that employees see the risk of termination of employment may increase their efforts to be more valuable to the organization and consequently not fired (Sverke and Hellgren, 2001).

Occupational Safety and Health (OSH) is one of the integrated maintenance programs in order to reduce accidents. Mathis and Jackson (2003:245) states that safety refer to the protection of a person's physical wellbeing against work-related injuries. While Health refers to the general condition of physical, mental and emotional stability in general. While Occupational Safety and Health (OSH) according to Mondy and Noe (2005:360) is the protection of employees from injuries caused by work-related accidents. Safety risks are aspects of the work environment that can cause fire, electric shock, cuts, bruises, sprains, broken bones, loss of limbs, hearing and vision. Occupational health is freedom from physical violence. Health risks are the factors of work itself such as working beyond a specified time period, an environment that can create emotion, stress or physical impairment.

The importance of maintaining the safety and health of members of the organization has been widely recognized among managers because healthy and fit employees, in the physical sense and in the mental sense of psychologists, will be able to show excellent performance, high motivation and low absenteeism (Siagian, 2008:263). With the Occupational Safety and Health $(\mathrm{OSH})$ program, very closely related to the performance of employees because if within the company creates a comfortable working atmosphere, safe and peaceful, then employees will feel appreciated and cared for. Therefore, the safety and health program will be able to improve the performance of these employees.

Performance is the achievement or result of one's effort to achieve certain goals. Performance refers to employee performance measured by the standards or criteria set by the company (Mathis and Jackson, 2003:78). Furthermore Wibowo (2014:7) suggests performance is the result of work that has a strong relationship with the organization's strategic goals, customer satisfaction, and contribute to the economy. While Rivai (2005:309) states performance is a real behavior that is displayed every person as a work performance generated by employees in accordance with its role in the company.

It can be concluded that performance is the activity of employees in doing the work and the results achieved from the work or about what to do and how to do it. Occupational Safety and Health (OSH) and Performance Issues always get management attention because it is closely related to the productivity of the company. Occupational Safety and Health (OHS) and Performance Standards programs affect how many employees contribute to the company. 
Based on the description of background and literature review is then the hypothesis proposed in this study are as follows:

H1: Job Insecurity has a positive and significant influence on firefighter performance in East Kutai.

$\mathrm{H}$ 2: Occupational Safety and Health (OSH) has a positive and significant influence on firefighter performance in East Kutai.

\section{RESEARCH METHODOLOGY}

The population used in this research is firefighters who are directly involved in field in Fire and Rescue Department of East Kutai Regency which amounted to 183 people. The sampling method in this research is done by random sampling technique so that every employee in the population has the same probability to be a member of the sample. Of the population of 183 employees determined the number of samples of 126 people.

Data collection methods in this study using primary data. That is done by using questionnaires delivered directly to respondents in the form of closed questions. The research variables are first operationalized so that the measurement can be done. Measurement data conducted in this study is Likert scale with the following sizes: $1=$ Strongly disagree. $2=$ Disagree, $3=$ Quite agree, $4=$ Agree, $5=$ Strongly agree. Furthermore, to answer the research hypothesis, the data were analyzed by using Multiple Linear Regression Analysis Method with the help of SPSS program version 21.00.

\section{RESULTS}

The result of analysis of the influence of Job Insecurity and Occupational Safety and Health (OSH) to performance can be presented from the results of multiple regression analysis as in the following table.

\section{Table Coefficients ${ }^{\mathrm{a}}$}

\begin{tabular}{|c|c|c|c|c|c|c|}
\hline \multirow{3}{*}{$\begin{array}{l}\text { Model } \\
1\end{array}$} & \multirow[b]{3}{*}{$\begin{array}{l}\text { (Constan } \\
\text { t) }\end{array}$} & \multicolumn{2}{|c|}{$\begin{array}{l}\text { Unstandardized } \\
\text { Coefficients }\end{array}$} & $\begin{array}{l}\text { Standardized } \\
\text { Coefficients }\end{array}$ & \multirow[b]{2}{*}{$\mathrm{t}$} & \multirow[b]{2}{*}{ Sig. } \\
\hline & & B & Std. Error & Beta & & \\
\hline & & ,903 & 1,907 & & ,473 & ,637 \\
\hline & Job & & & & & \\
\hline & Insecurit & ,302 & ,089 & ,239 & 3,415 & ,001 \\
\hline & $\begin{array}{l}\text { y } \\
\text { OSH }\end{array}$ & ,563 & ,071 & ,558 & 7,961 &, 000 \\
\hline $\mathrm{R}$ & & $0,643^{\mathrm{a}}$ & & $\mathrm{F}$ & & \\
\hline R Squa & & 0,413 & & Sig & & \\
\hline Adj. R & Square & 0,404 & & & & \\
\hline
\end{tabular}

a. Dependent Variable: Performance

b. Predictors : (Constant), Job Insecurity, OSH

Source : Output Research's Results, 2017 
The result of the analysis shows the coefficient of determination $\mathrm{R}$ square equal to 0,413 and correlation $(\mathrm{R})$ equal to 0,643 . The amount of contribution of Job Insecurity and Occupational Safety and Health (OSH) variable to the performance of fire and rescue officers in East Kutai can be seen from Adjusted $\mathrm{R}$ Square value of 0.404 . This means that $40,4 \%$ Performance variables will be affected by independent variables, namely Job Insecurity and Occupational Safety and Health (OSH). While the remaining 59,6\% performance variables will be influenced by other variables that are not discussed in this study.

Meanwhile, to know the level of significance of independent variables to dependent variables simultaneously then tested by using the F test (Fisher Test). Test $\mathrm{F}$ is done by comparing Fcount with Ftable. Obtained Fcount value of 43,357 then the value compared with Ftabel with a significant level of 0.05, obtained $\mathrm{F}$ table value of $=3.07$ so that $\mathrm{F}$ count $=43,357$ bigger than $\mathrm{F}$ table $=$ 3.07 (Fcount> Ftabel). Taking into account of these values, the hypothesis that there is a significant influence between Job Insecurity and Occupational Safety and Health $(\mathrm{OSH})$ variables on performance variables firefighters and rescue in East Kutai is acceptable.

To determine the effect of independent variables partially on the performance of firefighters and rescue in East Kutai is using t test, that is by comparing the value of $t_{\text {count }}$ to $t_{\text {table }}$ at a significant level of 0.05 or at $95 \%$ confidence. From the data in the table it appears that Job Insecurity has a significant influence on the performance of firefighters and rescue workers in East Kutai, it is shown by the value of $t$ test results where the value of $t_{\text {count }}$ $(3.415)>t$ table $(1.960)$ and significant value $0.001<0.05$. From the regression equation is known if Job Insecurity variable has positive value of regression coefficient equal to 0,302 . This means that this indicates that job insecurity has a positive effect in improving the performance of firefighters and rescue workers in East Kutai.

While the Occupational Safety and Health (OSH) variables also appear to have a significant influence on the performance of firefighters and rescue workers in East Kutai, where the t value (7.961) > t table (1.960) and the significant value $0.000<0.05$. From the regression equation is known if the variable Occupational Safety and Health (OSH) has a positive regression coefficient value of 0.563 . This means that Occupational Safety and Health has a positive influence in improving the performance of firefighters and rescue workers in East Kutai. Thus both independent variables have a significant influence on the performance of firefighters and rescue workers in East Kutai. Of these two variables, the Occupational Safety and Health (OSH) variable has the strongest influence on the performance of firefighters and rescue workers in East Kutai compared to Job Insecurity.

\section{DISCUSSION}

Based on research that has been done, shows that officers feel the discomfort in the work that makes the officers feel worried, causing feelings of insecurity and excessive worries. Job insecurity is a condition of powerlessness to maintain the desired sustainability in a threatening work situation (Greenhalgh and Rosenblatt, 2010). Unsafe feelings will have an impact on job attitudes of employees, even the desire for ever greater turnover. The result of research showing the influence of Job Insecurity on the performance of firefighters and rescue in East Kutai is supported by previous research 
conducted by Chirumbolo (2005) and EO Lucky (2013) who found Job Insecurity have significant influence on Performance. Job insecurity raises the impact of psychological aspects, such as decreased job satisfaction, decreased creativity, worries, feelings of depression and even cause the desire or intention of employees to stop working from work voluntarily according to his own choice.

Based on the analysis using multiple regression, the second hypothesis that there is influence between Occupational Safety and Health on the performance of firefighters and rescue in East Kutai has been proven and the hypothesis is acceptable. The impact is significant, so that the implementation of Occupational Safety and Health provided by the fire and rescue agency in East Kutai to its officers will be able to improve the performance of the officers themselves in the completion of their work. The results of this study are also reinforced by the opinion of Mangkunegara (2007:162), "in addition to aims to avoid work accidents in the company's production process, occupational safety and health programs also to improve enthusiasm, work harmonious and employee participation", with increased enthusiasm, and employee participation will affect employee performance.

It is expected that the department can ensure that firefighter keeps their current jobs for the long term as well as providing OSH, as Job Insecurity and Occupational Safety and Health (OSH) variables have a positive and significant impact on performance, firefighter gets better. Given the independent variables in the study this is a very important thing in affecting firefighter performance expected results of this study can used as a reference for researchers further to develop this study with consideration other variables such as workload, compatibility with co-workers and work environment which is another variable outside the already entered variable in this research.

\section{CONCLUSION}

This research showing Job Insecurity have significant influence on the Performance of firefighters and rescue in East Kutai. Job Insecurity instead tend to be directly damaging for the organization. Job insecurity can cause unsafe feelings and will have an impact on job attitudes of employees, such as decreased job satisfaction, decreased creativity, worries, feelings of depression and even cause the desire or intention of employees to stop working from work voluntarily. This research also showing that there is influence between Occupational Safety and Health on the performance of firefighters and rescue in East Kutai. The Occupational Safety and Health provided by the fire and rescue agency in East Kutai to its officers will be able to improve the performance of the officers themselves in the completion of their work. It is expected that the company can maintain and improve services to occupational health and safety programs, because employee health and safety variables have the most dominant influence on employee performance. Thus the performance of employees will be better.

\section{References}

Band, D.C., \& Tustin, C. M. (1995). Strategic Downsizing. Management Decision, 33/8:36-41 
Cheng, G., \& Chan, D. (2008). Who Suffers More from Job Insecurity? A Meta Analytic Review. Applied Psychology: An International Review, 57 (2), 272-303.

Chirumbolo, A., \& Areni, A. (2005). The influence of job insecurity on job performance and absenteeism: the moderating effect of work attitudes. Journal of Industrial Psychology, 31, 65-71.

Lucky, E.O., Minai, M.S., \& Rahman, H. A. (2013). Impact of Job Security on The Organizational Performance in a Multiethnic Environment. Research Journal of Business Management, 7 (1): 64-70.

Greenhalgh, L., \& Rosenblatt, Z. (1984). Job insecurity: Toward conceptual clarity. Academy of Management Review, 3, 438-448.

Greenhalgh, L., \& Rosenblatt Z. (2010). Evolution of Research on Job Insecurity. International Studies of Management. \& Organization, 40, 619.

Mangkunegara, A. (2007). Manajemen Sumber Daya Manusia Perusahaan. Cetakan Ketujuh. Bandung : Remaja Rosdakarya.

Mathis, R. L., \& Jackson, J. J. (2003). Human Resorce Management. Tenth Edition. Ohio: Thomson Corporation.

Mohr, G. B. (2000). The changing significance of different stressors after the announcement of bankruptcy: A longitudinal investigation with special emphasis on job insecurity. Journal of Organizational Behavior, 21, 337359.

Mondy, R. W., \& Noe, R. M. (2005). Human Resource Management. Ninth Edition. USA: Prentice Hall.

Rivai, V. (2005). Manajemen Sumber Daya Manusia. Jakarta: Raja Grafindo Persada.

Rosenblatt, Z., Talmud, I., \& Ruvio, A. (1999). A gender-based framework of the experience of job insecurity and its effects on work attitudes. European Journal of Work and Organizational Psychology, 8(2), 197217.

Siagian, S. P. (2008). Manajemen Sumber Daya Manusia. Jakarta: Bumi Aksara.

Sverke, M., \& Hellgren, J. (2001). Exit, voice, and loyalty reactions to job insecurity in Sweden: Do unionized and non-unionized members differ? British Journal of Industrial Relations, 39, 167-182.

Sverke, M., \& Hellgren, J. (2002). The nature of job insecurity: Understanding employment uncertainty on the brink of a new millennium. Applied Psychology. An International Review, 51, 23-42.

Wibowo. (2014). Manajemen Kinerja. Edisi Keempat. Jakarta: Rajawali Pers. 